Article

\title{
The Effect of Annealing Treatment and Atom Layer Deposition to Au/Pt Nanoparticles-Decorated $\mathrm{TiO}_{2}$ Nanorods as Photocatalysts
}

\author{
Shuang Shuang ${ }^{1 \text { (D) }}$ and Zhengjun Zhang ${ }^{2, *}$ (D) \\ 1 State Key Laboratory of New Ceramics and Fine Processing, School of Materials Science and Engineering, \\ Tsinghua University, Beijing 100084,China; shuangshuang_buct@163.com \\ 2 Key Laboratory of Advanced Materials (MOE), School of Materials Science and Engineering, \\ Tsinghua University, Beijing 100084, China \\ * Correspondence: zjzhang@tsinghua.edu.cn; Tel.: +86-10-62797033
}

Received: 2 January 2018; Accepted: 7 February 2018; Published: 9 February 2018

\begin{abstract}
The wide band gap of $\mathrm{TiO}_{2}$ hinders the utilization of visible light in high-performance photocatalysis. Herein, vertically aligned Ti nanopillar arrays (NPAs) were grown by the glancing angle deposition method (GLAD) and then thermally oxidized into $\mathrm{TiO}_{2} \mathrm{NPAs}$. The metallic nanoparticles (NPs) were fabricated by successive ion layer adsorption and reaction (SILAR) method. And we covered ultrathin $\mathrm{TiO}_{2}$ layer on $\mathrm{Au} / \mathrm{Pt}$ NPs decorated NPA using atomic layer deposition (ALD) method and did annealing process in the end. The photoelectrochemical (PEC) performance and dye degradation have been studied. We find the dye degradation efficiency of best combination reaches up to 1.5 times higher than that of original $\mathrm{Au} / \mathrm{Pt}-\mathrm{TiO}_{2}$ sample under visible light irradiation. The $\mathrm{TiO}_{2}$ ALD layer effectively protects the nanostructure from corrosion and helps the transmission of electrons to the electrolyte. By controlling the annealing temperature we could achieve a matched band gap due to change in noble metal particle size. Our work demonstrates that rational design of composite nanostructures enhances the usage of broader wavelength range light and optimizes photocatalytic degradation of organic pollutants in practical applications.
\end{abstract}

Keywords: $\mathrm{TiO}_{2} \mathrm{NPAs}$; atomic layer deposition; $\mathrm{Au} / \mathrm{Pt} \mathrm{NPs}$; photoelectrochemistry; visible light

\section{Introduction}

Composite nanomaterials have attracted researchers' attention due to their multifunctional applications in various fields, such as semiconductor photocatalysts for pollutants degradation. $\mathrm{TiO}_{2}$, due to its nontoxic nature, long-term photostability, low cost, and relatively efficient photocatalytic activity, has been investigated in this context for many years [1]. However, it is just effective and operative in the UV region because of its wide band gap $(\sim 3.0 \mathrm{eV})$ [2] and the UV region only accounts for about $\sim 4 \%$ in the solar radiation [3]. Moreover, the photogenerated electron-hole pairs have a quite short recombination time that also hinders further utilization of $\mathrm{TiO}_{2}$. Previously, a lot of work has been done to address these issues with apporaches such as noble-metal decoration [4], ion doping [5-7] or alteration of the unit morphology [8]. Nowadays the quantum size effect has been focused on as another hot topic $[9,10] . \mathrm{TiO}_{2}$ nanostructures tend to aggregate easily, which effects the efficiency in practical experiments. Here we use the glancing angle deposition (GLAD) technique to fabricate $\mathrm{TiO}_{2}$ nanopillar arrays (NPAs) vertically on substrates which are conveniently recycled and guarantee enough reaction surface area during the whole process.

Nanostructured noble metals could have a collective coherent oscillation of surface electrons which enables noble metals nanoparticles (NPs) to present surface plasmon resonance (SPR) effects [11,12]. These kinds of nanostructures show enhanced performance in a broad light range including the 
visible as well as the UV region [13-15], so $\mathrm{TiO}_{2}$ is usually combined with other semiconductors to form composites which possess certain functions such as photocatalytic properties. Li et al. [16] have designed a $\mathrm{CdS}-\mathrm{Au}-\mathrm{TiO}_{2}$ sandwich nanorod array capable of producing a photocurrent of $4.07 \mathrm{~mA} \cdot \mathrm{cm}^{-2}$ at $0 \mathrm{~V}$ (vs. $\mathrm{Ag} \mid \mathrm{AgCl}$ ) under full solar spectrum irradiation. It also showed a maximum solar-to-chemical energy conversion efficiency of $2.8 \%$, which is much higher than that of pure $\mathrm{TiO}_{2}$. Herein $\mathrm{Au}$ NPs serve as plasmonic photosensitizers and form a Schottky barrier with $\mathrm{TiO}_{2}$. $\mathrm{CdS}$ and $\mathrm{TiO}_{2}$ are band gap matched, which enhances the excited separation of electrons and holes. As for the synthesis of noble metal particles on nanostructures, there are many ways to achieve this such as chemical vapour deposition [17], sol-gel synthesis [18], hydrothermal methods [19] and successive ion layer adsorption and reaction (SILAR) [20]. Here we have co-decorated both Au and Pt NPs on the surface of nanorods through the SILAR method because of the easy preparation in room temperature.

Corrosion always happens on nanostructures during the degradation process [21]. In order to protect nanostructures and suppress the recombination, a metal oxide thin layer such as $\mathrm{Al}_{2} \mathrm{O}_{3}$ [22], $\mathrm{SnO}_{2}$ [23] and $\mathrm{ZrO}_{2}$ [24] is always applied through atomic layer deposition (ALD) or other methods [25,26]. George et al. have employed $\mathrm{Al}_{2} \mathrm{O}_{3}$ and $\mathrm{TiO}_{2} \mathrm{ALD}$ when fabricating an ultrathin barrier film on a $\mathrm{Cu}$ substrate to prevent water corrosion [27]. As for catalysis, Lu et al. [28] have applied a $\mathrm{TiO}_{2}$ overcoat on Au catalysts by ALD. They found higher activity in $\mathrm{CO}$ oxidation and investigated the reaction mechanism. This technique could control the thickness of layers at the nanoscale by setting the number of deposition cycles and self-limiting the reaction of dosed precursor gases.

Herein, we report co-decorated $\mathrm{Au} / \mathrm{Pt} \mathrm{NPs}$ on $\mathrm{TiO}_{2} \mathrm{NPAs}$ with a wrapped up $\mathrm{TiO}_{2}$ ALD layer. $\mathrm{TiO}_{2}$ nanopillar arrays (NPAs) were first deposited on $\mathrm{SiO}_{2}$, F-doped $\mathrm{SnO}_{2}$ (FTO) and Si substrates through the GLAD method. Later metallic NPs ( $\mathrm{Au}$ and Pt) were deposited on the NPAs using the SILAR method [29]. Then, we coated a $\mathrm{TiO}_{2}$ ALD layer on the nanostructured material. In order to improve the stability of the photocatalyst, we annealed the sample at different temperatures. The whole process is shown in Figure 1. We have also studied the effect of annealing on the photocatalytic performance of our fabricated nanostructures.

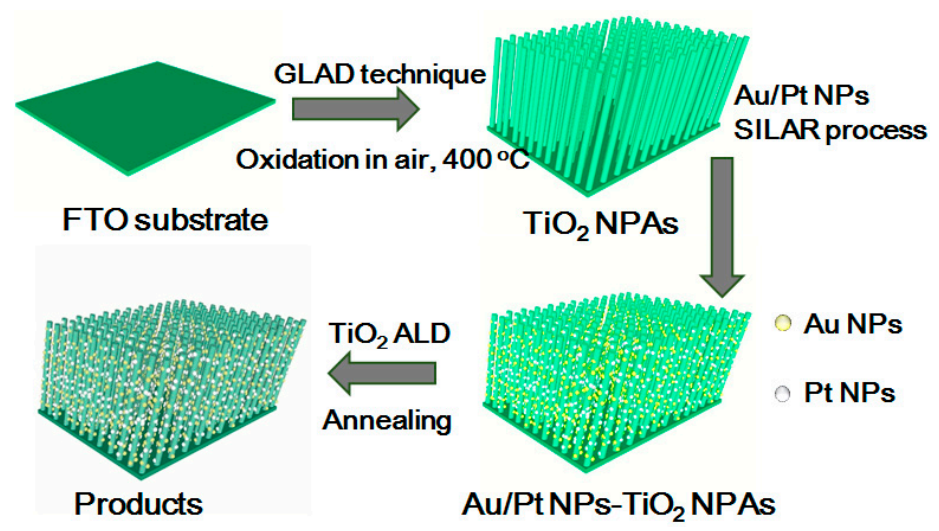

Figure 1. Schematic illustration of the preparation of $\mathrm{Au} / \mathrm{Pt}-\mathrm{TiO}_{2}$ nanorod arrays (NPAs) with ALD and the annealing treatment.

\section{Results and Discussion}

\subsection{Characterization of Materials}

Figure 2 presents the SEM images of pure $\mathrm{TiO}_{2}$ NPAs (Figure 2a), coated only with noble metal NPs (Figure 2b), Au/Pt-TiO 2 NPAs coated with one, three, and four cycles of $\mathrm{TiO}_{2} \mathrm{ALD}$ (Figure 2c,e,f), and a magnified image of $\mathrm{Au} / \mathrm{Pt}-\mathrm{TiO}_{2} \mathrm{NPAs}$ coated with one cycle of $\mathrm{TiO}_{2}$ ALD (Figure 2d), respectively. From the top view we can see that the Au and Pt nanoparticles are distributed on the $\mathrm{TiO}_{2}$ NPAs' surface (Figure $2 b$ ), where they appear as little white dots randomly spread on the 
$\mathrm{TiO}_{2}$ NPA surface. It is difficult to distinguish the modifications in the nanostructures only from the morphology, because ALD application and the annealing treatment do not change them remarkably.
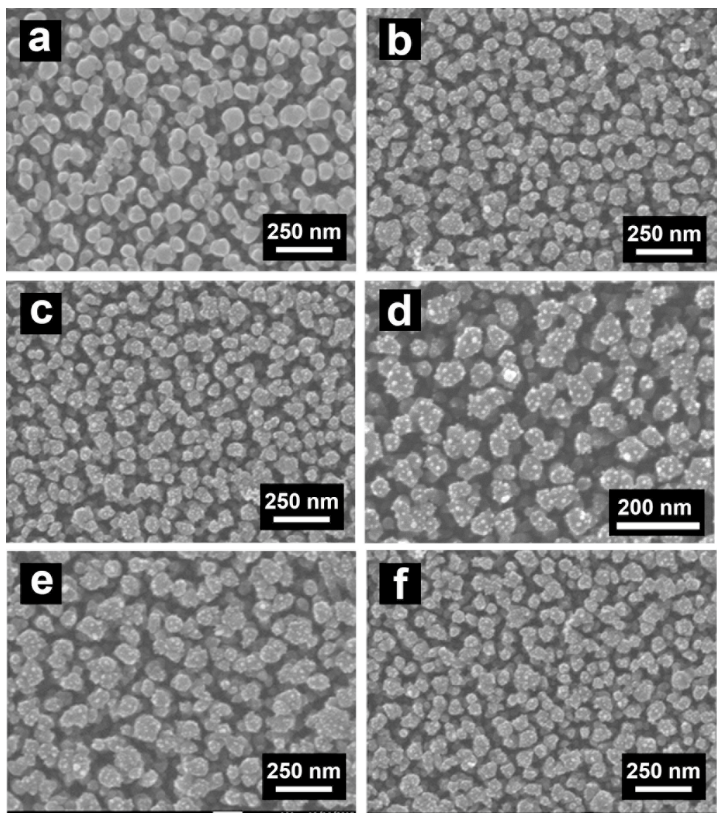

Figure 2. SEM images of: (a) $\mathrm{TiO}_{2} \mathrm{NPAs}$; (b) $\mathrm{Au} / \mathrm{Pt}-\mathrm{TiO}_{2} \mathrm{NPAs}$; (c) $\mathrm{Au} / \mathrm{Pt}-\mathrm{TiO}_{2} \mathrm{NPAs}$ coated with one ALD layer; (d) magnified image of $\mathrm{Au} / \mathrm{Pt}-\mathrm{TiO}_{2} \mathrm{NPAs}$ coated with one ALD layer, $\mathrm{Au} / \mathrm{Pt}-\mathrm{TiO} \mathrm{N}_{2} \mathrm{NPAs}$ coated with three (e); or four (f) ALD layers.

In order to improve the degree of crystallinity, we tried anneal the samples after ALD coating. Here we choose three different temperature $\left(200{ }^{\circ} \mathrm{C}, 300^{\circ} \mathrm{C}\right.$ and $400{ }^{\circ} \mathrm{C}$, respectively). The TEM images in Figure 3 show $\mathrm{TiO}_{2}$ without annealing (Figure 3a,b), $300{ }^{\circ} \mathrm{C}$ (Figure $3 \mathrm{~d}, \mathrm{e}$ ) and $400{ }^{\circ} \mathrm{C}$ (Figure 3g,h) annealing based on two cycles of $\mathrm{ALD} \mathrm{TiO}_{2}$. The $\mathrm{TiO}_{2} \mathrm{NPAs}$ have a size of approximately $200 \mathrm{~nm}$ in length and a diameter of about $50 \mathrm{~nm}$ (Figure 3a). The calculation and test of lattice fringes, $(\mathrm{d}=0.325 \mathrm{~nm}, 0.236 \mathrm{~nm}$ and $0.194 \mathrm{~nm})$ matches with the lattice plane of rutile (110), Au (111) and $\mathrm{Pt}$ (111), respectively [30]. The generation of metal-semiconductor nanojunctions can result in the formation of a Schottky junction, which can dramatically affect the optoelectronic properties of the material. When $\mathrm{Au}$ and $\mathrm{Pt}$ contact to $\mathrm{TiO}_{2}$, the charge carriers would redistribute. Electrons move from the n-type semiconductor (higher Fermi level) to the metal (lower Fermi level) until reaching equilibrium. The Schottky barrier which could efficiently capture excited electrons. These facts would all be favourable to interfacial charge transfer between each component and improve the photocatalytic performance of the whole system eventually [31]. Our experimental results show that the interface of ALD thin film becomes clearer with higher crystallinity. This phenomenon indicates that the degree of crystallinity of our nanostructures improves with annealing treatment [32]. Here the number of ALD cycles is indicated before the term "ALD" in the sample name.

To confirm the valence of metallic NPs, the $2 \mathrm{ALD} / \mathrm{Au} / \mathrm{Pt}-\mathrm{TiO}_{2} \mathrm{NPAs}$ without annealing sample was investigated by the XPS technique (Figure 4). The intense doublet of $\mathrm{Pt}(70.2$ and $73.6 \mathrm{eV}$ ) and $\mathrm{Au}$ (83.7 and $87.4 \mathrm{eV}$ ) correspond to metallic $\mathrm{Pt}^{0}, \mathrm{Au}^{0}$ [33]. These results show that the $\mathrm{Au}$ and $\mathrm{Pt} \mathrm{NPs}$ were both successfully fabricated on $\mathrm{TiO}_{2} \mathrm{NPAs}$. Furthermore the outer layer is also $\mathrm{TiO}_{2}$. The O $1 \mathrm{~s}$ XPS spectrum (Figure 4c) can be fitted by two peaks: a main peak showing at a binding energy of $529.8 \mathrm{eV}$ which is attributed to lattice ' $\mathrm{O}$ ' and another one located at $531.4 \mathrm{eV}$ that refers to the hydroxyls or water adsorbed on the surface of the nanostructure. The Ti $2 \mathrm{p}$ spectrum includes doublets of Ti 2 $\mathrm{p}_{1 / 2}$ and Ti $2 \mathrm{p}_{3 / 2}$ at binding energies of 466.1 and $460.3 \mathrm{eV}$ which confirm the existence of $\mathrm{Ti}^{4+}$ cations in $\mathrm{TiO}_{2}$ [34]. There are two peak located around 464.6 and $458.8 \mathrm{eV}$ indicating Ti-O-C $2 \mathrm{p}_{1 / 2}$ and Ti-O-C 
$2 \mathrm{p}_{3 / 2}$ bonds which are due to the ALD reaction process which indicates intermediate products formed after the reaction between tetrakis(dimethylamido)titanium(IV) and $\mathrm{H}_{2} \mathrm{O}$ [35].

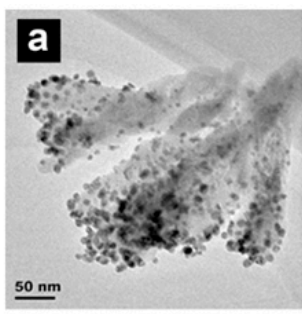

d
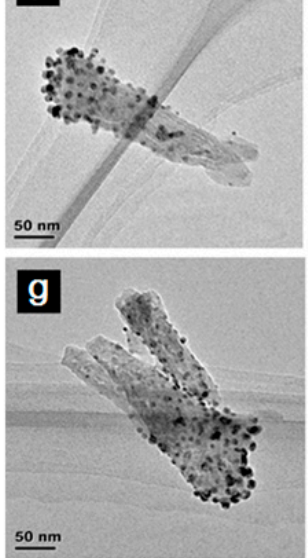
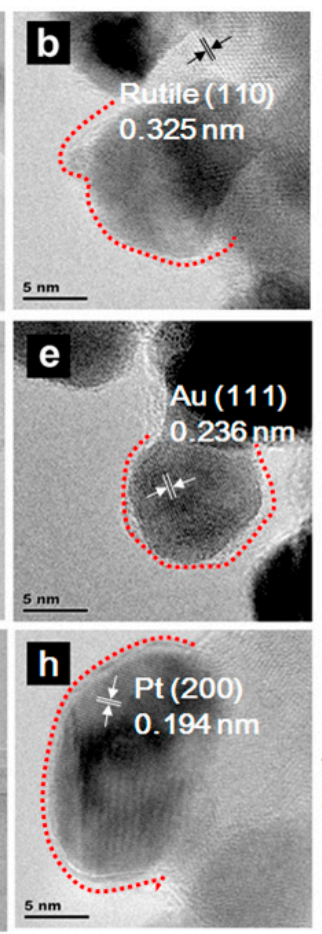

(c) Average: $7.5 \mathrm{~nm}$

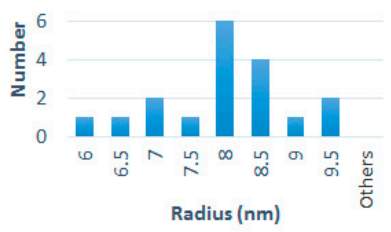

(f) Average: $8.9 \mathrm{~nm}$

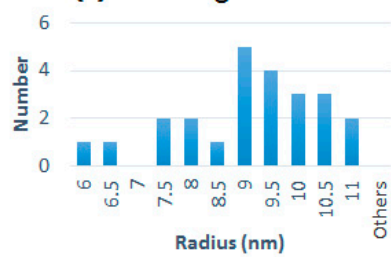

(i) Average: $11.0 \mathrm{~nm}$

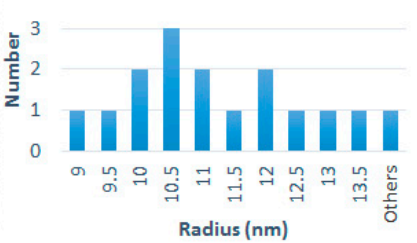

Figure 3. TEM images, HRTEM images and particles size statistics of (a-c) $2 \mathrm{ALD} / \mathrm{Au} / \mathrm{Pt}-\mathrm{TiO}_{2} \mathrm{NPAs}$; (d-f) $2 \mathrm{ALD} / \mathrm{Au} / \mathrm{Pt}-\mathrm{TiO}_{2} \mathrm{NPAs}$ annealing at $200{ }^{\circ} \mathrm{C} ;(\mathrm{g}-\mathbf{i}) 2 \mathrm{ALD} / \mathrm{Au} / \mathrm{Pt}-\mathrm{TiO}_{2} \mathrm{NPAs}$ annealing at 300 ${ }^{\circ} \mathrm{C}$.

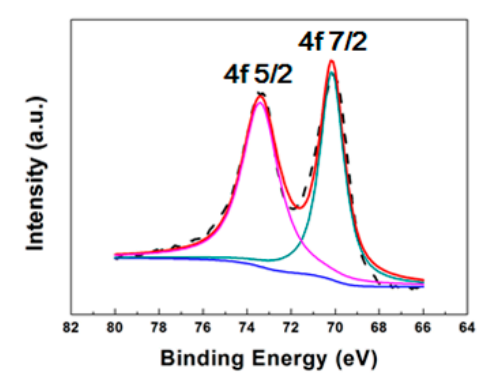

(a)

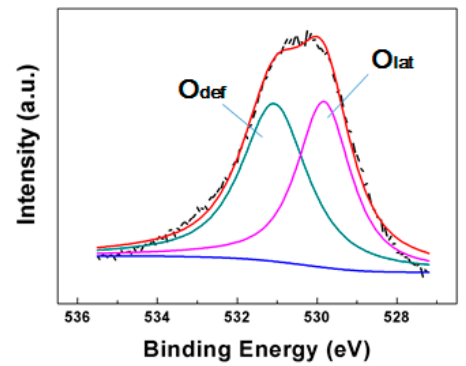

(c)

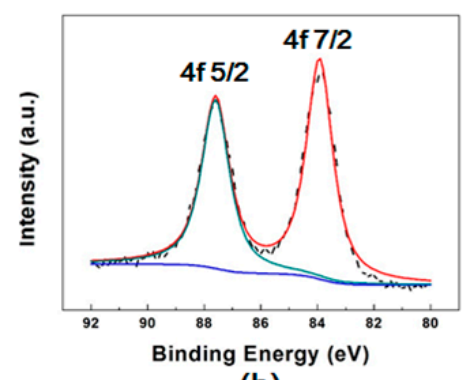

(b)

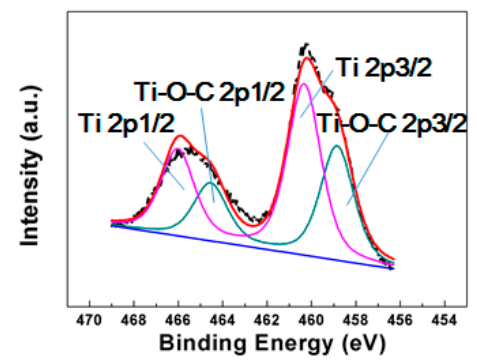

(d)

Figure 4. XPS spectrum of 2ALD/Au/Pt-TiO 2 NPAs: (a) Pt 4f; (b) Au 4f; (c) O 1s; (d) Ti 2p.

Figure 5 show on-off PEC plots for $\mathrm{Au} / \mathrm{Pt}_{-} \mathrm{TiO}_{2}$ NPAs with ALD coatings (1, 2, 3, 4 layers) and the corresponding annealed samples' test result. The figures compare the photocurrent density of the series 
of samples with increased potential from -0.1 to $+0.6 \mathrm{~V}$. According to Figure $5 \mathrm{a}$, $\mathrm{b}$, we can see that the currents between light on/off are all about $15 \mu \mathrm{A} \mathrm{cm}^{-2}$, which doesn't change much even under $200{ }^{\circ} \mathrm{C}$ heat treatment. However, when annealed at $300{ }^{\circ} \mathrm{C}$ and $400{ }^{\circ} \mathrm{C}$ for $1 \mathrm{~h}$, the photocurrent generally increased. Especially, $300{ }^{\circ} \mathrm{C}$ annealing with two ALD layer cycles and $400{ }^{\circ} \mathrm{C}$ with three layers reach to 40 and $35 \mu \mathrm{A} \mathrm{cm}{ }^{-2}$ (Figure $5 \mathrm{c}, \mathrm{d}$ ). They are enlarged about 1.5 2 times compared to the previous one without annealing treatment.

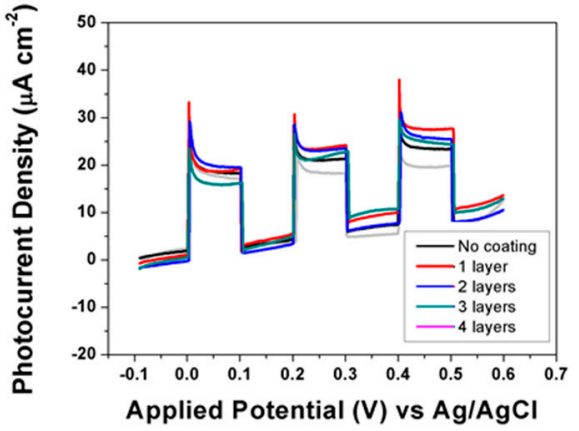

(a)

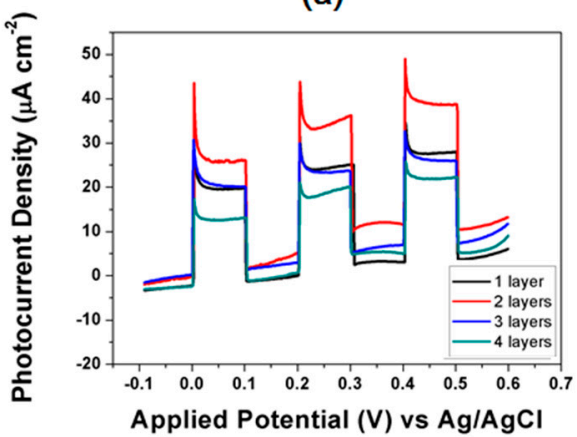

(c)

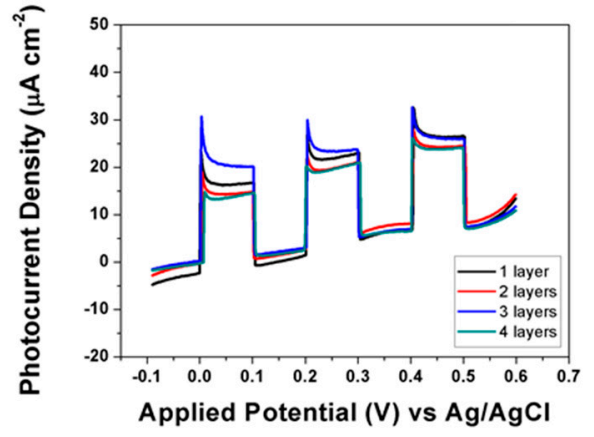

(b)

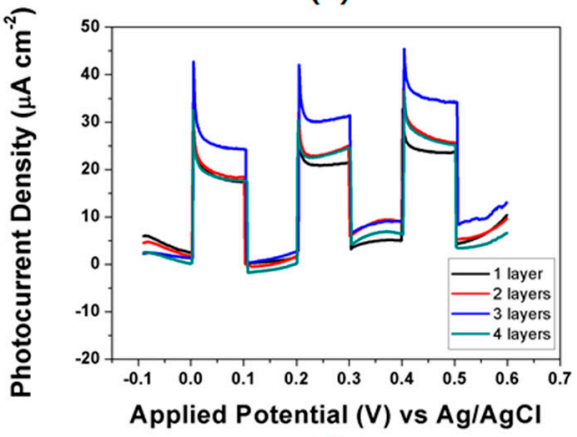

(d)

Figure 5. $j-V$ characteristics (with light on/off) of (a) Au/Pt-TiO ${ }_{2} \mathrm{NPAs}$ and coated with 1 4 ALD layers; $\mathrm{Au} / \mathrm{Pt}-\mathrm{TiO}_{2} \mathrm{NPAs}$ coated with $1 \sim 4 \mathrm{ALD}$ layers under $200{ }^{\circ} \mathrm{C}(\mathbf{b}) ; 300{ }^{\circ} \mathrm{C}(\mathbf{c}) ; 400{ }^{\circ} \mathrm{C}(\mathbf{d})$ annealing treatment.

We also investigated the photocatalytic performance and degradation of Methylene Blue (MB) dye under visible light for $1 \mathrm{~h}$. The $\mathrm{Au} / \mathrm{Pt}-\mathrm{TiO}_{2} \mathrm{NPs}$ sample shows a degradation efficiency of $49.3 \%$. Furthermore we analyzed the degradation efficiency of our composite nanostructures with different ALD cycle numbers and annealing temperature, as mentioned in Table 1. Our experiments show that after ALD coating and heat treatment most samples showed an improvement in the photocatalytic degradation. The sample without ALD shows lower efficiency because the metal NPs are easily photocorroded without the protection of the outer coating layer [36]. Compared with the ALD-coated samples, the excited electrons could not only transfer through $\mathrm{TiO}_{2} \mathrm{NPAs}$, but also ALD $\mathrm{TiO}_{2}$ which surrounds the metal NPs. Specifically the $2 \mathrm{ALD} / \mathrm{Au} / \mathrm{Pt}-\mathrm{TiO}_{2} \mathrm{NPAs}$ sample (with annealing at $300{ }^{\circ} \mathrm{C}$ ) shows the highest degradation efficiency which is enhanced by about $150 \%$ compared with the blank sample. However, on the contrary the efficiency of composite nanostructures annealed at $400{ }^{\circ} \mathrm{C}$ goes down. For samples with the same annealing temperature, two cycles and three cycles usually show better performance. Through our experiemntal data calculations, annealing mainly influences and enhances the degradation efficiency of the MB pollutant. Usually demethylation would happen on MB when degraded by $\mathrm{TiO}_{2}$, thus the absorption peak of the dye solution will cause a blue shift [37]. 
Table 1. Degradation efficiency (\%) under visible light $(\lambda \geq 420 \mathrm{~nm})$ of MB.

\begin{tabular}{ccccc}
\hline ALD Cycle/Annealing Temperature & No Annealing Treatment & $\mathbf{2 0 0}{ }^{\circ} \mathbf{C}$ & $\mathbf{3 0 0}{ }^{\circ} \mathbf{C}$ & $\mathbf{4 0 0}^{\circ} \mathbf{C}$ \\
\hline No ALD & 49.3 & 52.4 & 58.9 & 51.7 \\
ALD1 & 63.3 & 63.3 & 74.7 & 61.4 \\
ALD2 & 67.7 & 64.2 & 75.3 & 66.9 \\
ALD3 & 62.6 & 67.6 & 65.3 & 67.3 \\
ALD4 & 63.7 & 67.2 & 57 & 66.5 \\
\hline
\end{tabular}

In order to study the effect of annealing treatment in depth, diffuse reflectance UV-vis spectra of five different products $\left(\mathrm{TiO}_{2} \mathrm{NPAs}, \mathrm{Au} / \mathrm{Pt}-\mathrm{TiO}_{2} \mathrm{NPAs}\right.$ and $\mathrm{Au} / \mathrm{Pt}-\mathrm{TiO}_{2} \mathrm{NPAs}$ with annealing for $200{ }^{\circ} \mathrm{C}, 300^{\circ} \mathrm{C}, 400^{\circ} \mathrm{C}$ ) are presented in Figure S1, which are also calculated with the Kubelka-Munk function. The equation of the band gap energy $\left(E_{g}\right)$ is $\alpha E_{\text {photon }}=K\left(E_{\text {photon }}-E_{g}\right)^{1 / 2}$, where $\alpha, K$, $\mathrm{E}_{\mathrm{g}}$ and $\mathrm{E}_{\text {photon }}$ are respectively the absorption coefficient, a constant, the band gap energy and the discrete photon energy. Here we plot and calculate the intercept of an extrapolated linear fit [20].

$\mathrm{TiO}_{2}$ NPAs exhibit a UV absorption peak at $300 \sim 400 \mathrm{~nm}$. The metal decoration of $\mathrm{TiO}_{2} \mathrm{NPAs}$ indicates a remarkable improvement in the light absorption at about $480 \mathrm{~nm}$ due to the surface plasmon absorption of the decorated Au NPs [38], but we didn't find any obvious difference in the UV adsorption after the annealing treatments, thus we turned our attention to the size of the metal NPs. Here we compare the statistical NPs radius according to the TEM images. The histograms are plotted in Figure 3c,f,i. From the average diameter statistics, the size of $2 \mathrm{ALD} / \mathrm{Au} / \mathrm{Pt}-\mathrm{TiO}_{2} \mathrm{NPAs}_{\text {without }}$ annealing and annealing under $300{ }^{\circ} \mathrm{C}$ and $400{ }^{\circ} \mathrm{C}$ increases with higher heat treatment from $7.5 \mathrm{~nm}$ to $11.0 \mathrm{~nm}$, but we could find that there is an extremum in the photoccatalytic properties, which means there probably exists an optimal NP diameter size.

\subsection{Photocatalytic Mechanism}

After visible light irradiation, strong SPR is excited by Au NPs [39]. During its dephasing, hot electrons are injected via Schottky junction into the conduction band (CB) for reduction reactions, leaving holes in the noble metal nanoparticles where oxidation reactions occur [40-42]. So in this system hot electrons shift from the surface of the $\mathrm{Au}$ NPs to the $\mathrm{TiO}_{2}$ conduction band [43]. The work function of $\mathrm{Pt}(\sim 5.40 \mathrm{eV}$ in vacuum [44]) is higher than that of $\mathrm{Au}(\sim 4.78 \mathrm{eV}$ in vacuum) which leads to the Fermi level of $\mathrm{Pt}$ being lower than that of $\mathrm{Au}$. Thus electrons would move from $\mathrm{Au}$ to $\mathrm{Pt}$ via $\mathrm{TiO}_{2}$. Here Pt NPs play a role as cocatalyst.

Here electrons can both decompose the dye and interact with electron acceptors $\left(\mathrm{O}_{2}\right)$ to create superoxide radicals $\left(\mathrm{O}_{2}{ }^{\bullet-}\right)$. At same time, the positively charged Au NPs would combine with $\mathrm{OH}^{-}$ into highly oxidizing species such as hydroxyl radicals, $\mathrm{OH} \bullet$ or oxidize the $\mathrm{MB}$ molecule directly. The whole reaction is presented in Figure 6a. It is necessary to be aware that a close $\mathrm{Au} / \mathrm{TiO}_{2}$ Schottky contact is due to the last-step annealing process. The treatment is helpful to produce an efficient visible-light photocatalyst [45]. Furthermore heterojunction arrays, which is the light trapping caused from the one-dimensional array nanostructure with matched bandgap, also improve the light absorption [46].

When the size reaches the nanoscale, the Fermi level of noble metal NPs usually improves with decreased size because of the quantum size effect. The mechanism is shown in Figure $6 \mathrm{~b}$. A suitable diameter could be achieved to match the band gap. Only this could convert electrons efficiently and suppress the combination of electrons and holes [47,48]. The energy level of Au NPs must stay higher than that of oxygen gas and lower than the $\mathrm{CB}$ of $\mathrm{TiO}_{2}$. When hot electrons are excited by visible light from $\mathrm{Au}$ NPs, just the rational energy level could let electrons move into the $\mathrm{CB}$ of $\mathrm{TiO}_{2}$ and be able to react with $\mathrm{O}_{2}$ to form $\mathrm{O}_{2}{ }^{\bullet-}$. Otherwise, if the energy of the Au NPs becomes too high, it won't transfer to $\mathrm{TiO}_{2}$; or if the energy becomes too low, it won't have enough energy to react with $\mathrm{O}_{2}$. What's more, 
if the particles become too big, they will also cover too much of the $\mathrm{TiO}_{2}$ 's reaction surface which in turn hinders the photocatalytic properties.

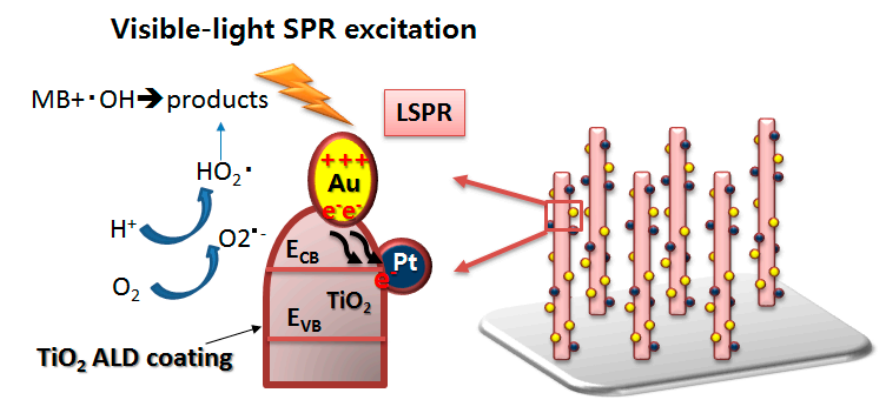

(a)

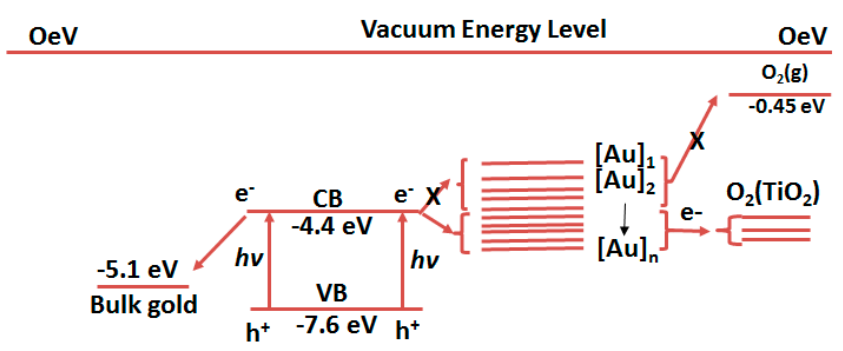

(b)

Figure 6. (a) The charge transfer process of $\mathrm{TiO}_{2} \mathrm{ALD} / \mathrm{Au} / \mathrm{Pt} / \mathrm{TiO}_{2} \mathrm{NPAs}$ under UV-vis lights; (b) Fermi level of nanoscale gold particles.

\section{Materials and Methods}

\subsection{Synthesis of $\mathrm{TiO}_{2} \mathrm{NPAs}$}

Firstly, Ti NPAs were fabricated via e-beam using the GLAD technique on several substrates (i.e., quartz, silicon and FTO). The chamber need to be evacuated to $1 \times 10^{-8}$ Torr before deposition. All substrates were cleaned using ultrasonication in acetone, ethanol and deionized (DI) water, respectively. The data of deposition was similar to that used in previous work [49]. After deposition, the thin films were oxidized in a tube furnace at $400^{\circ} \mathrm{C}$ for $2 \mathrm{~h}$.

\subsection{Metallic Nanoparticle Decoration on $\mathrm{TiO}_{2} \mathrm{NPAs}$}

$\mathrm{Au}$ and Pt NPs were reacted via the SILAR method with some modifications as previously published [49]. We dipped $\mathrm{TiO}_{2}$ successively into $\mathrm{HAuCl}_{4}$ (or $\mathrm{HPt}_{2} \mathrm{Cl}_{6}$ ) and reductant $\left(\mathrm{NaBH}_{4}\right)$ solutions in order to form NPs. The substrates were immersed into a certain concentration of $\mathrm{HAuCl}_{4}$ (or $\mathrm{HPt}_{2} \mathrm{Cl}_{6}$ ) solution, DI water, $1 \mathrm{mg} / \mathrm{mL} \mathrm{NaBH}_{4}$ solution, DI water respectively for $60 \mathrm{~s}$. This complete procedure is regarded as one cycle. The whole process was repeated until the desired cycle number was fabricated. $\mathrm{Au} / \mathrm{Pt}-\mathrm{TiO}_{2}$ NPAs samples were consecutively deposited by $\mathrm{Au}$ and Pt NPs individually five times.

\subsection{ALD Deposition}

$\mathrm{TiO}_{2}$ NPAs were placed in a custom-built reactor, and the substrate temperature was kept at $150{ }^{\circ} \mathrm{C}$ during the ALD process [50]. When pumped into the chamber, the precursor, tetrakis(dimethylamido)titanium(IV), was controlled at $110^{\circ} \mathrm{C}$ and water was at $40{ }^{\circ} \mathrm{C}$. A soaking step was inserted in order to confirm the sufficient diffusion of the reacting molecules on the surface of the nanostructures [51]. The precursor was first pumped using $200 \mathrm{~ms}$ and soaked for $5 \mathrm{~s}$, after which the chamber was evacuated for $20 \mathrm{~s}$. Later, $\mathrm{H}_{2} \mathrm{O}$ (gas) was pulsed for $5 \mathrm{~ms}$ and kept for $3 \mathrm{~s}$ to let them react, 
with a $20 \mathrm{~s}$ purge step at the end. This whole procedure can be regarded as one ALD cycle. The process is repeated until the desired thickness of $\mathrm{TiO}_{2}$ is achieved.

\subsection{Characterization}

The chemical nature, morphology and nanostructure of all samples were characterized by field-emission scanning electron microscopy (SEM, FE-SEM, JEOL-7001F, JEOL, Tokyo, Japan) and high-resolution transmission electron microscope (HRTEM, JEOL-2011, JEOL). The surface composition was determined by X-ray photoemission spectroscopy (XPS) measurements performed on a PHI 5300 instrument (Perkin Elmer, Waltham, MA, USA). Here the binding energy was calibrated with the C1s peak $(284.6 \mathrm{eV})$. The light absorption of materials were tested via a Perkin Elmer Lambda 35 UV-Vis spectrometer (Perkin Elmer) in the wavelength range between $375 \mathrm{~nm}$ and $900 \mathrm{~nm}$.

\subsection{Property Measurements}

The photocurrent density was measured by an electrochemistry workstation (CHI 660D, Chenhua Instrument, Shanghai, China). Here the film and substrates were regarded as the working electrode, while a $\mathrm{Ag} / \mathrm{AgCl}$ electrode (saturated $\mathrm{KCl}$ ) is used as a reference. Pt slices with specific shapes were applied as counter electrodes. A Xe lamp $(300 \mathrm{~W})$ was used as a light source with ultraviolet filter to intercept the UV light (wavelength shorter than $420 \mathrm{~nm}$ ). Photocurrent densities with increased potential from $-0.1 \sim+0.6 \mathrm{~V}$ bias vs $\mathrm{Ag} / \mathrm{AgCl}$ electrode were tested via a light on-off process. Here we selected intervals of $5 \mathrm{~s}$ for the switching time. The photocatalytic degradation performance was examined by using Methylene Blue $(\mathrm{MB})$ under visible light. The samples on a quartz substrate $(15 \mathrm{~mm} \times 15 \mathrm{~mm})$ were immersed in a $25 \mathrm{~mL}$ beaker containing $5 \mathrm{~mL}$ of $\mathrm{MB}(5 \mu \mathrm{M})$ solution. The samples remained in solution for half an hour before degradation to achieve an adsorption/desorption equilibrium. At the end of $1 \mathrm{~h}$ irradiation, we tested the concentration of MB by UV-Vis spectroscopy at its characteristic wavelength of $502 \mathrm{~nm}$. Both remaining percentage $\left(C / C_{0}\right)$ and degradation efficiency $\left(1-C / C_{0}\right) \times 100 \%$ were recorded. PEC experiments with light on-off at specific voltages were also performed to assess the photoelectrochemical properties. $0.1 \mathrm{M} \mathrm{Na}_{2} \mathrm{SO}_{4}$ aqueous solution was used as the electrolyte.

\section{Conclusions}

In conclusion, we have successfully prepared $\mathrm{TiO}_{2} \mathrm{ALD} / \mathrm{Au} / \mathrm{Pt}$ NPs-decorated $\mathrm{TiO}_{2}$ nanostructures with an annealing treatment. When compared with nanostructures without ALD and annealing treatment, the process shows a great improvement no matter whether in the degradation of dyes or photocurrent production under visible light. The $\mathrm{TiO}_{2} \mathrm{ALD}$ layers effectively protect the nanostructures from corrosion and make electrons accessible to the electrolyte. The annealing treatment could adjust the noble metal NPs into a band gap-matched nanoscale. The rational design of nanocomposites helps make the photocatalytic performance of $\mathrm{TiO}_{2}$ in the visible wavelength region more efficient. Thus this method offers an efficient way to achieve the maximum usage of solar energy for photocatalytic degradation of organic pollutants in practical applications.

Supplementary Materials: The supplementary materials are available online.

Acknowledgments: We greatly thank the supported from Chinese Ministry of Science and Technology (grant No. 2016YFE0104000) and the National Natural Science Foundation of China (grant No. 51372135).

Author Contributions: Shuang Shuang and Zhengjun Zhang conceived and designed the experiments; Shuang Shuang performed the experiments; Shuang Shuang analyzed the data; Zhengjun Zhang contributed reagents/materials/analysis tools; Shuang Shuang wrote the paper.

Conflicts of Interest: The authors declare no conflict of interest. 


\section{References}

1. Zhang, J.; Xu, Q.; Feng, Z.; Li, M.; Li, C. Importance of the relationship between surface phases and photocatalytic activity of $\mathrm{TiO}_{2}$. Angew. Chem. Int. Ed. 2008, 47, 1766-1769. [CrossRef] [PubMed]

2. Zhou, K.; Zhu, Y.; Yang, X.; Jiang, X.; Li, C. Preparation of graphene- $\mathrm{TiO}_{2}$ composites with enhanced photocatalytic activity. New J. Chem. 2011, 35, 353-359. [CrossRef]

3. Cowan, A.J.; Durrant, J.R. Long-lived charge separated states in nanostructured semiconductor photoelectrodes for the production of solar fuels. Chem. Soc. Rev. 2013, 42, 2281-2293. [CrossRef] [PubMed]

4. Yu, J.; Xiong, J.; Cheng, B.; Liu, S. Fabrication and characterization of $\mathrm{Ag}-\mathrm{TiO}_{2}$ multiphase nanocomposite thin films with enhanced photocatalytic activity. Appl. Catal. B Environ. 2005, 60, 211-221. [CrossRef]

5. Kowalska, E.; Remita, H.; Colbeau-Justin, C.; Hupka, J.; Belloni, J. Modification of titanium dioxide with platinum ions and clusters: Application in photocatalysis. J. Phys. Chem. C 2008, 112, 1124-1131. [CrossRef]

6. Subramanian, V.; Wolf, E.E.; Kamat, P.V. Catalysis with $\mathrm{TiO}_{2}$ /gold nanocomposites. Effect of metal particle size on the fermi level equilibration. J. Am. Chem. Soc. 2004, 126, 4943-4950. [CrossRef] [PubMed]

7. Zhang, L.; Yu, J.C.; Yip, H.Y.; Li, Q.; Kwong, K.W.; Xu, A.-W.; Wong, P.K. Ambient light reduction strategy to synthesize silver nanoparticles and silver-coated $\mathrm{TiO}_{2}$ with enhanced photocatalytic and bactericidal activities. Langmuir 2003, 19, 10372-10380. [CrossRef]

8. $\quad$ Liang, Y.; Wang, H.; Sanchez Casalongue, H.; Chen, Z.; Dai, H. $\mathrm{TiO}_{2}$ nanocrystals grown on graphene as advanced photocatalytic hybrid materials. Nano Res. 2010, 3, 701-705. [CrossRef]

9. Chen, Z.; Liu, J.; Qiu, S.; Dawson, G.; Chen, W. The shape-specific photocatalytic efficiency of quantum size $\mathrm{TiO}_{2}$ nanoparticles. Catal. Commun. 2012, 21,1-4. [CrossRef]

10. Lin, H.; Huang, C.P.; Li, W.; Ni, C.; Shah, S.I.; Tseng, Y.-H. Size dependency of nanocrystalline $\mathrm{TiO}_{2}$ on its optical property and photocatalytic reactivity exemplified by 2-chlorophenol. Appl. Catal. B Environ. 2006, 68, 1-11. [CrossRef]

11. Zhang, Z.; Wang, W.; Gao, E.; Sun, S.; Zhang, L. Photocatalysis coupled with thermal effect induced by SPR on Ag-loaded $\mathrm{Bi}_{2} \mathrm{WO}_{6}$ with enhanced photocatalytic activity. J. Phys. Chem. C 2012, 116, 25898-25903. [CrossRef]

12. Rayalu, S.S.; Jose, D.; Mangrulkar, P.A.; Joshi, M.; Hippargi, G.; Shrestha, K.; Klabunde, K. Photodeposition of aunps on metal oxides: Study of SPR effect and photocatalytic activity. Int. J. Hydrogen Energy 2014, 39, 3617-3624. [CrossRef]

13. Linic, S.; Christopher, P.; Ingram, D.B. Plasmonic-metal nanostructures for efficient conversion of solar to chemical energy. Nat. Mater. 2011, 10, 911-921. [CrossRef] [PubMed]

14. Shahjamali, M.M.; Bosman, M.; Cao, S.W.; Huang, X.; Saadat, S.; Martinsson, E.; Aili, D.; Tay, Y.Y.; Liedberg, B.; Loo, S.C.J.; et al. Gold coating of silver nanoprisms. Adv. Funct. Mater. 2012, 22, 849-854. [CrossRef]

15. Ide, Y.; Matsuoka, M.; Ogawa, M. Efficient visible-light-induced photocatalytic activity on gold-nanoparticle-supported layered titanate. J. Am. Chem. Soc. 2010, 132, 16762-16764. [CrossRef] [PubMed]

16. Li, J.; Cushing, S.K.; Peng, Z.; Senty, T.; Meng, F.; Bristow, A.D.; Manivannan, A.; Wu, N. Solar hydrogen generation by a CdS- $\mathrm{Au}-\mathrm{TiO}_{2}$ sandwich nanorod array enhanced with Au nanoparticle as electron relay and plasmonic photosensitizer. J Am Chem Soc. 2014, 136, 8438. [CrossRef] [PubMed]

17. Coyle, J.P.; Gordon, P.G.; Wells, A.P.; Mandia, D.J.; Sirianni, E.R.; Yap, G.P.A.; Barry, S.T. Thermally robust gold and silver iminopyrrolidinates for chemical vapor deposition of metal films. Chem. Mater. 2013, 25, 4566-4573. [CrossRef]

18. Bharathi, S.; Fishelson, N.; Lev, O. Direct synthesis and characterization of gold and other noble metal nanodispersions in sol-gel-derived organically modified silicates. Langmuir 1999, 15, 1929-1937. [CrossRef]

19. Belousov, O.V.; Belousova, N.V.; Sirotina, A.V.; Solovyov, L.A.; Zhyzhaev, A.M.; Zharkov, S.M.; Mikhlin, Y.L. Formation of bimetallic $\mathrm{Au}-\mathrm{Pd}$ and $\mathrm{Au}-\mathrm{Pt}$ nanoparticles under hydrothermal conditions and microwave irradiation. Langmuir 2011, 27, 11697-11703. [CrossRef] [PubMed]

20. Xie, Z.; Liu, X.X.; Wang, W.P.; Liu, C.; Li, Z.C.; Zhang, Z.J. Enhanced photoelectrochemical properties of $\mathrm{TiO}_{2}$ nanorod arrays decorated with CdS nanoparticles. Sci. Technol. Adv. Mater. 2014, 15, 055006. [CrossRef] [PubMed] 
21. Zhao, H.; Chen, J.; Rao, G.; Deng, W.; Li, Y. Enhancing photocatalytic $\mathrm{CO}_{2}$ reduction by coating an ultrathin $\mathrm{Al}_{2} \mathrm{O}_{3}$ layer on oxygen deficient $\mathrm{TiO}_{2}$ nanorods through atomic layer deposition. Appl. Surf. Sci. 2017, 404, 49-56. [CrossRef]

22. Le Formal, F.; Tetreault, N.; Cornuz, M.; Moehl, T.; Gratzel, M.; Sivula, K. Passivating surface states on water splitting hematite photoanodes with alumina overlayers. Chem. Sci. 2011, 2, 737-743. [CrossRef]

23. Xi, L.; Chiam, S.Y.; Mak, W.F.; Tran, P.D.; Barber, J.; Loo, S.C.J.; Wong, L.H. A novel strategy for surface treatment on hematite photoanode for efficient water oxidation. Chem. Sci. 2013, 4, 164-169. [CrossRef]

24. Li, T.C.; Góes, M.S.; Fabregat-Santiago, F.; Bisquert, J.; Bueno, P.R.; Prasittichai, C.; Hupp, J.T.; Marks, T.J. Surface passivation of nanoporous $\mathrm{TiO}_{2}$ via atomic layer deposition of $\mathrm{ZrO}_{2}$ for solid-state dye-sensitized solar cell applications. J. Phys. Chem. C 2009, 113, 18385-18390. [CrossRef]

25. Pavlenko, M.; Siuzdak, K.; Coy, E.; Jancelewicz, M.; Jurga, S.; Iatsunskyi, I. Silicon/TiO 2 core-shell nanopillar photoanodes for enhanced photoelectrochemical water oxidation. Int. J. Hydrogen Energy 2017, 42, 30076-30085. [CrossRef]

26. Sampath, S.; Maydannik, P.; Ivanova, T.; Shestakova, M.; Homola, T.; Bryukvin, A.; Sillanpää, M.; Nagumothu, R.; Alagan, V. Efficient solar photocatalytic activity of $\mathrm{TiO}_{2}$ coated nano-porous silicon by atomic layer deposition. Superlattices Microstruct. 2016, 97, 155-166. [CrossRef]

27. Abdulagatov, A.I.; Yan, Y.; Cooper, J.R.; Zhang, Y.; Gibbs, Z.M.; Cavanagh, A.S.; Yang, R.G.; Lee, Y.C.; George, S.M. $\mathrm{Al}_{2} \mathrm{O}_{3}$ and $\mathrm{TiO}_{2}$ atomic layer deposition on copper for water corrosion resistance. ACS Appl. Mater. Interfaces 2011, 3, 4593-4601. [CrossRef] [PubMed]

28. Wang, C.; Wang, H.; Yao, Q.; Yan, H.; Li, J.; Lu, J. Precisely applying $\mathrm{TiO}_{2}$ overcoat on supported Au catalysts using atomic layer deposition for understanding the reaction mechanism and improved activity in CO oxidation. J. Phys. Chem. C 2016, 120, 478-486. [CrossRef]

29. Tanaka, A.; Nakanishi, K.; Hamada, R.; Hashimoto, K.; Kominami, H. Simultaneous and stoichiometric water oxidation and $\mathrm{Cr}(\mathrm{VI})$ reduction in aqueous suspensions of functionalized plasmonic photocatalyst $\mathrm{Au} / \mathrm{TiO}_{2}-\mathrm{Pt}$ under irradiation of green light. ACS Catal. 2013, 3, 1886-1891. [CrossRef]

30. Shuang, S.; Lv, R.; Xie, Z.; Zhang, Z. Surface plasmon enhanced photocatalysis of Au/Pt-decorated $\mathrm{TiO}_{2}$ nanopillar arrays. Sci. Rep. UK 2016, 6, 26670. [CrossRef] [PubMed]

31. Su, J.; Feng, L.; Zhang, Y.; Liu, Z. The modulation of schottky barriers of metal-MoS 2 contacts via bn- $\mathrm{MoS}_{2}$ heterostructures. Phys. Chem. Chem. Phys. 2016, 18, 16882-16889. [CrossRef] [PubMed]

32. Ismail, A.A.; Bahnemann, D.W. Mesoporous titania photocatalysts: Preparation, characterization and reaction mechanisms. J. Mater. Chem. 2011, 21, 11686-11707. [CrossRef]

33. Cao, L.; Tong, L.; Diao, P.; Zhu, T.; Liu, Z. Kinetically controlled pt deposition onto self-assembled Au colloids: Preparation of $\mathrm{Au}$ (core)-Pt (shell) nanoparticle assemblies. Chem. Mater. 2004, 16, 3239-3245. [CrossRef]

34. Erdem, B.; Hunsicker, R.A.; Simmons, G.W.; Sudol, E.D.; Dimonie, V.L.; El-Aasser, M.S. Xps and ftir surface characterization of $\mathrm{TiO}_{2}$ particles used in polymer encapsulation. Langmuir 2001, 17, 2664-2669. [CrossRef]

35. Bronneberg, A.C.; Höhn, C.; van de Krol, R. Probing the interfacial chemistry of ultrathin ALD-grown $\mathrm{TiO}_{2}$ films: An in-line XPS study. J. Phys. Chem. C 2017, 121, 5531-5538. [CrossRef]

36. Bakke, J.R.; Pickrahn, K.L.; Brennan, T.P.; Bent, S.F. Nanoengineering and interfacial engineering of photovoltaics by atomic layer deposition. Nanoscale 2011, 3, 3482-3508. [CrossRef] [PubMed]

37. Awala, H.; Leite, E.; Saint-Marcel, L.; Clet, G.; Retoux, R.; Naydenova, I.; Mintova, S. Properties of methylene blue in the presence of zeolite nanoparticles. New J. Chem. 2016, 40, 4277-4284. [CrossRef]

38. Contreras-Caceres, R.; Dawson, C.; Formanek, P.; Fischer, D.; Simon, F.; Janke, A.; Uhlmann, P.; Stamm, M. Polymers as templates for $\mathrm{Au}$ and $\mathrm{Au} @ \mathrm{Ag}$ bimetallic nanorods: UV-vis and surface enhanced raman spectroscopy. Chem. Mater. 2013, 25, 158-169. [CrossRef]

39. Kominami, H.; Tanaka, A.; Hashimoto, K. Mineralization of organic acids in aqueous suspensions of gold nanoparticles supported on cerium(IV) oxide powder under visible light irradiation. Chem. Commun. 2010, 46, 1287-1289. [CrossRef] [PubMed]

40. Gomes Silva, C.; Juárez, R.; Marino, T.; Molinari, R.; García, H. Influence of excitation wavelength (UV or visible light) on the photocatalytic activity of titania containing gold nanoparticles for the generation of hydrogen or oxygen from water. J. Am. Chem. Soc. 2011, 133, 595-602. [CrossRef] [PubMed]

41. Warren, S.C.; Thimsen, E. Plasmonic solar water splitting. Energy Environ. Sci. 2012, 5, 5133-5146. [CrossRef] 
42. Mubeen, S.; Lee, J.; Singh, N.; Krämer, S.; Stucky, G.D.; Moskovits, M. An autonomous photosynthetic device in which all charge carriers derive from surface plasmons. Nat. Nanotechnol. 2013, 8, 247. [CrossRef] [PubMed]

43. Szabo, Z.; Furo, I.; Csoregh, I. Combinatorial multinuclear nmr and x-ray diffraction studies of uranium(vi)-nucleotide complexes. J. Am. Chem. Soc. 2005, 127, 15236-15247. [CrossRef] [PubMed]

44. Trasatti, S. Work function, electronegativity, and electrochemical behaviour of metals. J. Electroanal. Chem. Interfacial Electrochem. 1971, 33, 351-378. [CrossRef]

45. Ding, D.; Liu, K.; He, S.; Gao, C.; Yin, Y. Ligand-exchange assisted formation of $\mathrm{Au} / \mathrm{TiO}_{2}$ schottky contact for visible-light photocatalysis. Nano Lett. 2014, 14, 6731-6736. [CrossRef] [PubMed]

46. Zhang, X.; Zhang, X.; Zhang, X.; Zhang, Y.; Bian, L.; Wu, Y.; Xie, C.; Han, Y.; Wang, Y.; Gao, P. Znse nanoribbon/Si nanowire $\mathrm{p}-\mathrm{n}$ heterojunction arrays and their photovoltaic application with graphene transparent electrodes. J. Mater. Chem. 2012, 22, 22873-22880. [CrossRef]

47. Panayotov, D.A.; Frenkel, A.I.; Morris, J.R. Catalysis and photocatalysis by nanoscale $\mathrm{Au} / \mathrm{TiO}_{2}$ : Perspectives for renewable energy. ACS Energy Lett. 2017, 2, 1223-1231. [CrossRef]

48. Jakob, M.; Levanon, H.; Kamat, P.V. Charge distribution between UV-irradiated $\mathrm{TiO}_{2}$ and gold nanoparticles: Determination of shift in the fermi level. Nano Lett. 2003, 3, 353-358. [CrossRef]

49. Peljo, P.; Manzanares, J.A.; Girault, H.H. Contact potentials, fermi level equilibration, and surface charging. Langmuir 2016, 32, 5765-5775. [CrossRef] [PubMed]

50. Xie, Z.; Liu, X.; Wang, W.; Wang, X.; Liu, C.; Xie, Q.; Li, Z.; Zhang, Z. Enhanced photoelectrochemical and photocatalytic performance of $\mathrm{TiO}_{2}$ nanorod arrays/CdS quantum dots by coating $\mathrm{TiO}_{2}$ through atomic layer deposition. Nano Energy 2015, 11, 400-408. [CrossRef]

51. Roelofs, K.E.; Brennan, T.P.; Dominguez, J.C.; Bailie, C.D.; Margulis, G.Y.; Hoke, E.T.; McGehee, M.D.; Bent, S.F. Effect of $\mathrm{Al}_{2} \mathrm{O}_{3}$ recombination barrier layers deposited by atomic layer deposition in solid-state CdS quantum dot-sensitized solar cells. J. Phys. Chem. C 2013, 117, 5584-5592. [CrossRef]

Sample Availability: Samples of the compounds are available from the authors.

(C) 2018 by the authors. Licensee MDPI, Basel, Switzerland. This article is an open access article distributed under the terms and conditions of the Creative Commons Attribution (CC BY) license (http:/ / creativecommons.org/licenses/by/4.0/). 